\title{
A study of effects of intellectual capital on organizational performance: A case study of Keshavarzi bank branch in Semnan, Iran
}

\author{
AliAkbar Aminbeidokhti ${ }^{\mathrm{a}}$ and Sadegh Darvishkhadem ${ }^{\mathbf{b}^{*}}$
}

${ }^{a}$ Department of Management, University of Semnan, Semnan, Iran

${ }^{b}$ Master Student in Department of Management, Islamic Azad University, Semnan Branch, Semnan, Iran

\begin{tabular}{|c|c|}
\hline A R T I C L E I N F O & A B S T R A C T \\
\hline $\begin{array}{l}\text { Article history: } \\
\text { Received July 10, } 2011 \\
\text { Received in Revised form } \\
\text { October, 3, } 2011 \\
\text { Accepted } 15 \text { January } 2012 \\
\text { Available online } \\
\text { 18 January } 2012 \\
\text { Keywords: } \\
\text { Intellectual capital } \\
\text { Human capital } \\
\text { Structure capital } \\
\text { Organizations performance } \\
\text { Client capital } \\
\text { Iran Keshavarzi Bank }\end{array}$ & $\begin{array}{l}\text { The new millennium is started with rapid growth on knowledge and investment and these two } \\
\text { items play essential role to create and increase organizational value. Intellectual capital is often } \\
\text { described as intangible assets for moving towards sustainable growth in values. Some studies } \\
\text { indicate there is a meaningful correlation between intellectual capital and organizations } \\
\text { performance. The goal of this research is to examine of this case in Iran and in one of the } \\
\text { biggest and most important province of country, Semnan and in one of its professional banks } \\
\text { named Bank of Keshavarzi. In order to collect data, a psychological questionnaire is used based } \\
\text { on an already existed version in the literature, which have been successfully implemented in } \\
\text { Canada and Malaysia. Cronbach Alpha was used to validate the data by considering importance } \\
\text { of statistical sample in this study. A random sampling method was used and } 188 \text { professional } \\
\text { personnel of Bank in five province were selected to answer the questionnaire. Results show a } \\
\text { meaningful relation between components of intellectual capital but this unity and relationship } \\
\text { was not confirmed between these components and organizational performance. The highest } \\
\text { effect is associated with organizations performance and costumer capital and the lowest effect } \\
\text { is associated with human investment. }\end{array}$ \\
\hline
\end{tabular}

\section{Introduction}

The new century is known as economic century, which is based on industry and each company needs more physical investments to create more wealth. However, progressive century or 21 century is also known as economic century, which is based on knowledge management. Information development and high development of technology in this century has created extended change in human life and information relies on observable intellectual capital. Economic developments of current century emphasize on this reality that creating value is owed to non-observable investment more than, observable one. According to Bontis et al. (1999), we see a decline on traditional resource such as tangible assets and an increase on knowledge. In this condition, new content such as mental investment has been attracted more attention. Therefore, intellectual capital is original resource for economic and other factors of traditional production are placed in next preference stages.

\footnotetext{
* Corresponding author

E-mail addresses: sdk1355@gmail.com (S. Darvihkhadem) 
Pherson and Pik (2011) studied organizations performance measurement using economical and mental factors. Juma and Payna ( 2003) studied mental investment effects on organizations performance with high technology. Buma and Silverman (2004) studied and examined relationship between intellectual capital of component and deciding about economic risk and organization performance and effects of these components on future organization performance. Chen et al. (2004) studied intellectual capital is based on quality factor and reported a meaningful relationships between intellectual capital and organization performance. Shiu (2004) in his study examined mental investment effect on 3 years operations of 80 high technology organizations. Youndt and Snell (2004), in other research, studied the relationship between intellectual capital on organization performance.

Subramaniam and Youndt (2005) investigated the effects of each component of intellectual capital on different kinds of innovations among 93 organizations. Juma and McGee (2006) in their research studied the effects of each component of intellectual capital on organization performance for 1000 organizations in brazil between years of 2000 to 2005. Sebastion et al. (2007) examined intellectual capital and organization performance in Australia. Appuhami (2007) in his research also studied relationship between intellectual capital component on banking sector.

Bontis (1998) performed another investigation in Canada and his research and his colleagues (Bontis et al., 2000) in Malaysia showed that, there was a positive relationship between intellectual capital component and industry performance. Chen Goh (2005) measured mental investment in Malaysian Banks. Chin Chen et al. (2005) studied relationship among intellectual capital, values of share marketing and financial performance of share organizations in Taiwan. Kamath (2008) reported that human capital had more influence on benefit, and values of drug companies in India. Abdulsalam et al. (2011) evaluated intellectual capital performance in Kuwait Bank by use of VAIC ${ }^{\mathrm{TM} 1}$ model.

\subsection{Intellectual Capital (IC)}

In evolution of intellectual capital, there have been different ideas and point of views (Roos et al., 2001; Petty \& Guthrie, 2000; MCElroy, 2002; Chen et al., 2004; Broking, 1997; Bontis, 19982002). General view to these content and other available contents shows that there is a lack of unity between researches in presenting perfect content about IC but all of them agree that this content includes an observable asset of organizations such as human, structure and client.

\subsubsection{Human capital}

Intellectual capital shows knowledge entity of organizations performance. Bontis (1998) and Brooking (1998) believe that IC in one organization includes skills, ability to solve problem and methods of management. In fact, human capital is conceptual source of knowledge, which is obtained from clear and direct knowledge. Ferreira and Martines (2011) reported that human capital can change by social interaction, values correction and organizational obligation. Tamay el al. (2001) reported that high level of human capital can decrease the amount of time and necessary capital for obtaining information and solving problem. According to Freeeira and Martines (2011) human capital

is a reason for organizations to rely on knowledge and skills of their employees to grow and efficiency develop. (Sharabati et al., 2010; Reed et al., 2006).

\subsubsection{Structural Capital (SC)}

Structural capital include all the nonhuman source of knowledge in organizations consist of given sites, organization graph , performance instruction of process, performance design and totally, everything that has high value than financial value, for organization. Roos (1997) believes that 
structural capital is everything which is maintained after a person goes home at night. Structural capital includes intellectual assets, such as technical knowledge, marketing brand and benefit. Chen et al. (2004) believes that structural capital can help supportive personal develop intellectual performance and also work performance of organizations. In other words, organizations must provide ergonomic condition for developing structural action-human in order to form customer capital (CC).

\subsubsection{Customer Capital ( CC )}

Customer capital is available knowledge in market - founding channel and relation with customers (Stewart, 1997). Chen et al. (2004) categorized customer capital as market - finding ability, marketing level and customers faithful. In fact, this content includes both current values of organizations relation and potential value in future. Fetros and Bigi (2010) developed and categorized intellectual capital component . Fig. 1 presents all components of CI (Fetros \& Bigi, 2010).

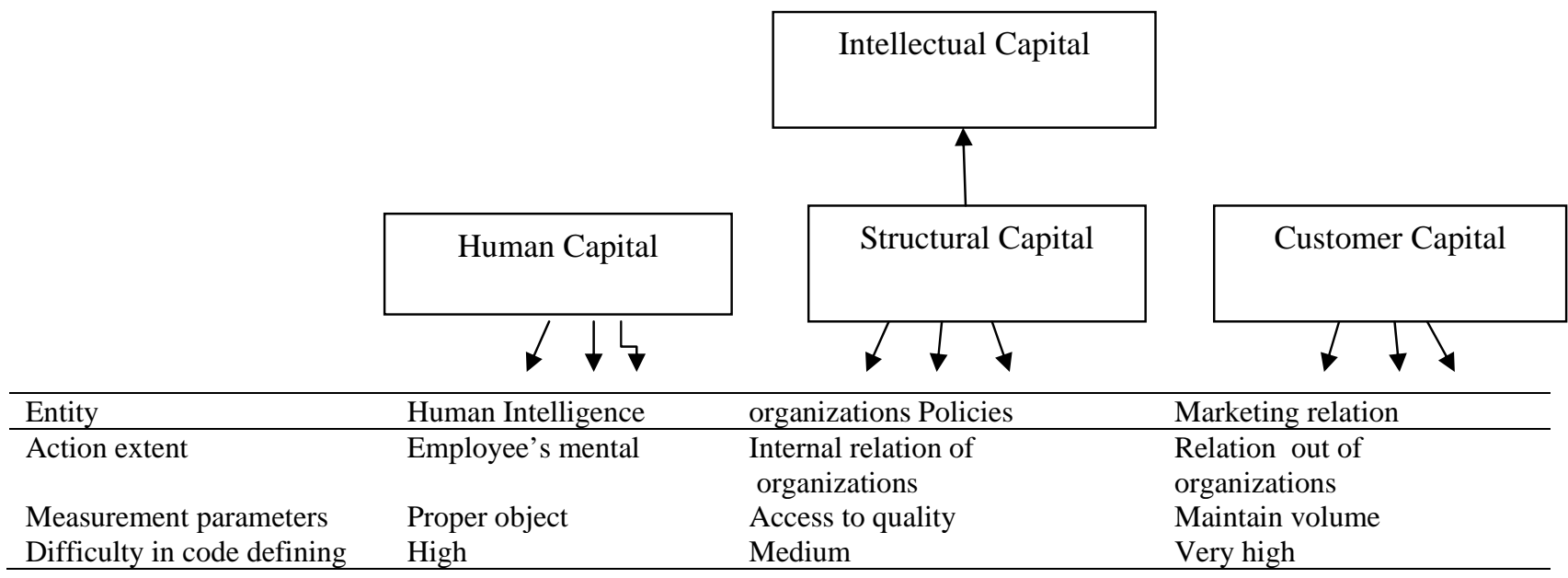

Fig. 1. Defining content of IC components

\section{Research Methodology}

\subsection{Conceptual Model of Research}

On the basis of theoretical studies about IC, we have adopted a model shown in Fig 2.

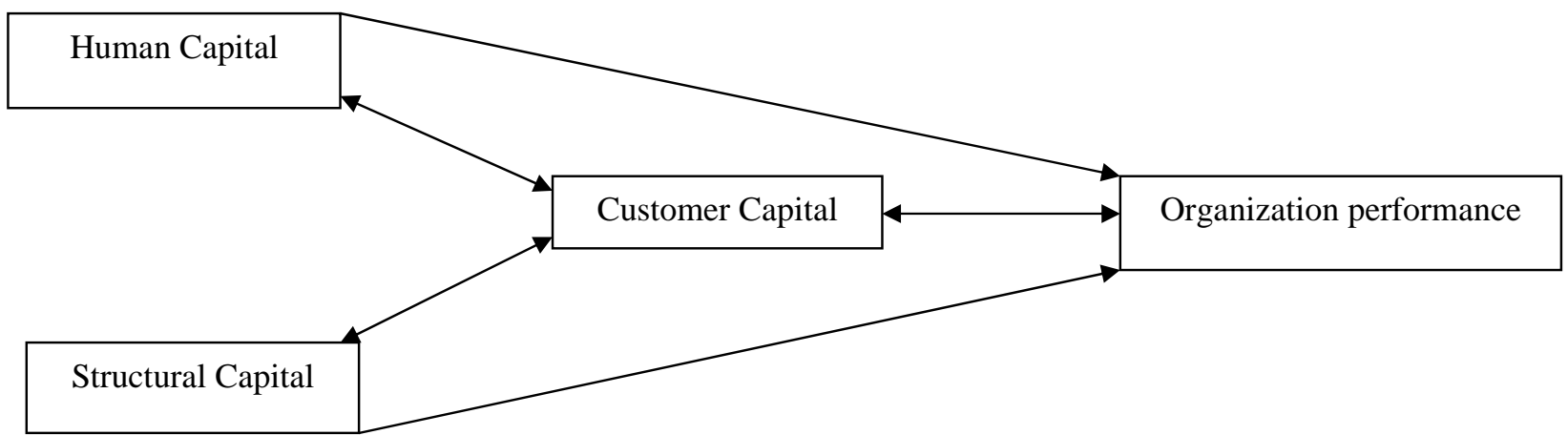

Fig. 2. Content model of research 


\subsection{Research method and type}

We first collect the necessary information in this area, by a questionnaire whose validity and reliability is determined, data was analyzed by use of SPSS19 software and finally proper results and recommendations are rendered. Table 2 shows details of our questionnaire based on Bontis's method.

\section{Table 2}

Human capital components

\begin{tabular}{|c|c|}
\hline \multicolumn{2}{|l|}{ Human Capital } \\
\hline $\mathrm{H}_{1}$ : Level of proper quality & $\mathrm{H}_{11}$ :The best performance of employees \\
\hline $\mathrm{H}_{2}$ : Plan of alternet treatment & $\mathrm{H}_{12}$ : plan of comprehensive employment \\
\hline $\mathrm{H}_{3}$ : Planning on new ideal & $\mathrm{H}_{13}:$ Large shape for leaving people \\
\hline $\mathrm{H}_{4}$ : Employs group work & $\mathrm{H}_{14}$ : Randomly thought about work \\
\hline $\mathrm{H}_{5}$ :Lack of internal communication & $\mathrm{H}_{15}:$ Lack of using in high ability \\
\hline $\mathrm{H}_{6}$ : Plan of new ideal & $\mathrm{H}_{16}$ : Learning from each other \\
\hline $\mathrm{H}_{7}$ : Development of employees skills level & $\mathrm{H}_{17}$ : Stating employer's idea \\
\hline $\mathrm{H}_{8}$ : Intelligence of employees & $\mathrm{H}_{18}$ : Using the highest level of employers \\
\hline $\mathrm{H}_{9}$ : The best employs in Bank & $\mathrm{H}_{19}$ : Decreasing level of employer's work \\
\hline $\mathrm{H}_{10}$ :Personal satisfactory & $\mathrm{H}_{20}$ : Personal satisfactory \\
\hline $\mathrm{C}_{10}$ : discussion with customers & $\mathrm{C}_{1}$ : general satisfactory of customers \\
\hline $\mathrm{C}_{11}$ : data distribution of customers & $\mathrm{C}_{2}$ : decreasing of solving problem for customers \\
\hline $\mathrm{C}_{12}$ : identification of target marketing & $\mathrm{C}_{3}$ : increasing marketing share \\
\hline $\mathrm{C}_{13}$ : lack of attention to customers process & $\mathrm{C}_{4}$ : the highest marketing share \\
\hline $\mathrm{C}_{14}$ : investment for customer request & $\mathrm{C}_{5}$ : long period of relation \\
\hline $\mathrm{C}_{15}$ : services with customers don't want & $\begin{array}{l}\mathrm{C}_{6} \text { : protection of services with the highest } \\
\text { increasing }\end{array}$ \\
\hline $\mathrm{C}_{16}$ : be sure about customer's relation & $\mathrm{C}_{7}:$ costumer's royalty \\
\hline \multirow[t]{2}{*}{$\mathrm{C}_{17}$ : receiving reflect from customers } & $\mathrm{C}_{8}$ : more choice with customers \\
\hline & $\mathrm{C}_{9}$ attitude to market by Bank \\
\hline \multicolumn{2}{|l|}{ Structural capital } \\
\hline \multicolumn{2}{|l|}{$\begin{array}{l}\text { S9: development of the highest idea in Bank } \\
\text { industry }\end{array}$} \\
\hline $\mathrm{S}_{10}$ : efficiency of Bank & $\mathrm{S}_{2}$ : development of income rather than expense \\
\hline $\mathrm{S}_{11}$ : systems of easy access to information & $\mathrm{S}_{3}$ : increasing expense for each employee \\
\hline $\mathrm{S}_{12}$ :banking innovation support & $\mathrm{S}_{4}$ : the highest income for each employee \\
\hline $\mathrm{S}_{13}$ : distinction in bank structure & $\mathrm{S}_{5}$ : decreasing of time for bargain \\
\hline $\begin{array}{l}\mathrm{S}_{14} \text { : supportive enrichment and lack of } \\
\text { knowledge share }\end{array}$ & $\mathrm{S}_{6}$ : the lowest time for doing bargain \\
\hline \multirow[t]{2}{*}{$\mathrm{S}_{15}:$ supportive climate } & $\mathrm{S}_{7}$ : Performance of new idea \\
\hline & $\mathrm{S}_{8}$ : support from idea development \\
\hline \multicolumn{2}{|l|}{ Bank performance } \\
\hline $\mathrm{P}_{6}$ : producing possess after presenting tax & $\mathrm{P}_{1}$ : bank management \\
\hline $\mathrm{P}_{7}$ : producing bargain presenting tax & $\mathrm{P}_{2}$ : future point of view (outlook) \\
\hline $\mathrm{P}_{8}$ : reaction against competition: & $\mathrm{P}_{3}$ : profit \\
\hline $\mathrm{P}_{9}$ : Level of successfully in presenting new services & $\mathrm{P}_{4}$ : profit growth \\
\hline $\mathrm{P}_{10}$ : Total performance of bank & $\mathrm{P}_{5}$ : bargain growth \\
\hline
\end{tabular}




\subsection{Data collection and sampling volume}

In present research, the proposed questionnaire of Bontis (1996-2002) has been adopted, which has already been used in Malaysia and Canada. In order to use this questionnaire, we have made some necessary changes to match the proposed study in banking sector. Verified questionnaire has 63 markers in 4 groups of human capital, structure, customer and structural performance. All questions are designed based on Likert scale from 1 to 5.

The questionnaires were distributed among 44 branches of Keshavarzi Bank in province of Semnan, Iran and we used a sample of 188 people. We have gathered opinions of different people from managers, experts and employees of branch in this province.

\subsection{Analysis stage and questionnaire evaluation}

In this stage, we must be sure that the measured factors are associated with the same content which is important for us. Cronbach Alpha (Cronbach, 1951) was 88\%, which shows good reliability and it means the data are fairly reliable.

\section{Analysis of data}

There are five main hypotheses associated with the proposed study of this paper.

\subsection{Hypotheses}

H1:There is a meaningful and positive relationship between human capital and customer`s capital.

H2: There is a meaningful and positive relationship between structural capital and human capital.

H3: There is a meaningful and positive relationship between structural capital and customer's capital.

H4: There is a meaningful and positive relationship between human capital and bank performance.

H5: There is a meaningful and positive relationship between customer capital and bank performance.

H6:There is a meaningful and positive relation between structural capital and bank performance.

Table 3 shows details of our survey.

Table 3

Final evaluation for meaningful variable of research

\begin{tabular}{lllllll}
\hline Hypothesis & H1 & H2 & H3 & H4 & H5 & H6 \\
\hline Correlation & 0.747 & 0.745 & 0.767 & -0.80 & -0.50 & -0.54 \\
Result & Confirm & Confirm & Confirm & Not Confirm & Not Confirm & Not Confirm \\
\hline
\end{tabular}

As we can observe from the results of Table 3 there is a meaningful positive human capital and customer`s capital, a positive relationship between structural capital and human capital and a positive relationship between structural capital and customer's capital.

However, we did not observe any positive relationship between human capital and bank performance, between customer capital and bank performance and between structural capital and bank performance. 


\subsection{Hypotheses}

Customer’s capital leads to development of performance in Keshavarzi Bank.

Structural capital leads to development of performance in Keshavarzi Bank.

Human capital leads to development of performance in Keshavarzi Bank.

\section{Table 4}

Final evaluation of different factors on organizations performance

\begin{tabular}{llll}
\hline Variable & Sig & Test proportion & Null hypothesis \\
\hline Customer capital & 0.604 & 0.5 & Accept \\
Structural capital & 0.605 & 0.5 & Accept \\
Human capital & 0.603 & 0.5 & Accept \\
\hline
\end{tabular}

We have calculated classified mean for all variables and Table 5 shows details of our computations. The results are meaningful when the significance level is less than 1 percent.

Table 5

Classifying of research factors

\begin{tabular}{lcccc}
\hline Variables & $\begin{array}{c}\text { Customer } \\
\text { Capital }\end{array}$ & Structural Capital & $\begin{array}{c}\text { Human } \\
\text { Capital }\end{array}$ & $\begin{array}{c}\text { Organizations } \\
\text { Performance }\end{array}$ \\
\hline Classifying Mean & 2.65 & 22.8 & 2.10 & 2.97 \\
\hline
\end{tabular}

As we can observe from the results of Table 4, no intellectual capital component has any impact on the performance of our bank case study. In other words, customer, structural and human capital do not have any impact on the performance of the bank when the significance level is one percent.

\section{Conclusion and presenting research recommendations}

In this paper, we have presented an empirical study to measure the impact of different intellectual capital on the performance of a bank. We have selected all branches of one of Iranian bank named Keshavarzi in the province of Semnan, Iran. The proposed study distributed questionnaires among 44 branches of the bank using a sample of 188 employees in different positions of management and regular personnel.

We have adopted a typical questionnaire proposed originally by Bontis and analyzed the results. The results of our study indicate that there was a meaningful positive human capital and customer`s capital, a positive relationship between structural capital and human capital and a positive relationship between structural capital and customer's capital. However, we did not observe any positive relationship between human capital and bank performance, between customer capital and bank performance and between structural capital and bank performance.

\section{Acknowledgement}

The authors would like to thank the anonymous referees for their constructive comments on earlier version of this work. 


\section{References}

Abdulsalam, F, Al-Qaheri, H, \& Al-khayyat, R. (2011). The Intellectual Capital performance of Kuwaiti Banks: An Application of VAIC ${ }^{\mathrm{TM} 1}$ Model. Journal of Scientific Research, 3(1), 88-96.

Appuhami R. (2007). The impact of intellectual capital on investors' Capital Gain on Shares: An empirical investigation in Thai banking, finance \& insurance sector. Journal of Internet Banking and Commerce, 12(1), 1-14.

Baum, J. A. C. \& Silverman, B. S. (2004). Picking winners or building them? Alliance, intellectual, and human capital as selection criteria in venture financing and performance of biotechnology startups. Journal of Business Venturing, 19(3), 411-436.

Brooking, A. (1996). Intellectual Capital: Core Assets for the Third Millennium 8 Enterprise. London, Thomson Business Press.

Bontis, N. (1997). Intellectual Capital Questionnaire. Institute for Intellectual Capital Research; Canada: Hamilton.

Bontis, N., Crossan, M., \& Hulland, J. (2002). Managing an organizational leaning system by aligning stocks and flows. Journal of Management Studies, 39(4), 437-466.

Bontis, N. (1996). There's a price on your head: Managing intellectual capital strategically. Ivey Business Quarterly, 60(4), 40-47.

Bontis, N. (1998). Intellectual Capital: An Exploratory study that develops measures and models. Management Decision, 36(2), 63-76.

Brooking, A. (1996). Intellectual Capital. International Thompson Business Press, London.

Bontis, N., Dragonetti, N.C., Jacobsen, K. \& Roos, G. (1999). The Knowledge toolbox: a review of the tools available to measure and manage intangible resources. European Management Journal, 17(4), 391-401.

Chen,J., Zhu, Z., \& Xie, Y.H. (2004). Measuring intellectual capital: a new model and empirical study. Journal of Intellectual capital, 5(1), 85-100.

Chen Goh, P. (2005). Intellectual capital performance of commercial banks in Malaysia. Journal of Intellectual Capital, 6(3), 385-396.

Chin Chen, M., Ju Cheng, S., \& Hwang, Y. (2005). An empirical investigation of the relationship between intellectual capital and firms' market value and financial performance. Journal of Intellectual Capital, 6(2), 159-176.

Cronbach, L. J. (1951). Coefficient alpha and the internal structure of tests. Psychometrika, 16(3), 297-334.

Ferreira, A.I, \& Martinez, L.F. (2011). Intellectual capital: perceptions of productivity and Investment. RAC, Curitiba, 15(2), 249-260.

Kamath G., \& Bharathi R. (2008). Intellectual Capital and corporate performance in Indian pharmaceutical industry. Journal of Intellectual Capital, 9(4), 684-704.

Petty, R., \& Guthrie, J. (2000). Intellectual capital literature review: measurement, reporting and management. Journal of Intellectual Capital, 1(2), 155-176.

Reed, K. K., Lubatkin, M., \& Srinivasan, N. (2006). Proposing and testing an intellectual capitalbasedview of the firm. Journal of Management Studies, 43(4), 867-893.

Roos, J., Roos, G, Dragonetti, N. C., \& Edvinsson, L. (1997). Intellectual Capital: Navigating in the New Business Landscape. London : Macmillan press Ltd.

Sharabati, A., Jawad, S., \& Bontis, N. (2010). Intellectual capital and business performance in the pharmaceutical sector of Jordan. Management Decision, 48(1), 105-131.

Stewart, T.A. (1997). Intellectual Capital: The New Wealth of Nations. Doubleday Dell Publishing Group, New York, NY.

Tamayo, A., Souza, M. G., Vilar, L. S., Ramos, J. L., Albernaz, J. V., \& Pereira, N. P. (2001). Prioridades axiológicas e comprometimento organizacional. Psicologia: Teoria e Pesquisa,17(1), 27-35. 
Kamath G., Bharathi R. (2008). Intellectual Capital and corporate performance in Indian pharmaceutical industry. Journal of Intellectual Capital, 9: 684-704.

McPherson, P.K., \& S. Pike (2001). Accounting Empirical Measurement and Intellectual Capital. Journal of Intellectual Capital, 2(3), 246-260.

Youndt, M. A., Subramaniam, M., \& Snell, S. A. (2004). Intellectual capital profiles: an examination of investments and returns. Journal of Management Studies, 41(2), 335-361.

Youndt, M. A., Snell, S. A., Dean, J. W., \& Lepak, D. P. (1996). Human resource management, manufacturing strategy, and firm performance. Academy of Management Journal, 39(4), 836-866. 